\title{
innovare
}

Ciencia y Tecnología

\section{PROCESO AMBIENTAL EFECTIVO: PROPUESTA DE NORMA MODELO PARA COSTA RICA}

\author{
Mario Peña Chacón ${ }^{1}$ \\ Coordinador y profesor de la Maestría en Derecho Ambiental de la Universidad de Costa Rica y de la \\ Facultad de Derecho de la misma universidad. Miembro de la Comisión de Derecho Ambiental de la \\ Unión Internacional para la Conservación de la Naturaleza (UICN) \\ Rafael González Ballar \\ Ex Decano, ex miembro del Consejo Universitario, Profesor de la Facultad de Derecho de la \\ Universidad de Costa Rica \\ (Recibido: Enero, 2017/ Aceptado: Julio, 2017)

\section{Resumen $^{2}$} \\ El derecho ambiental necesita verse reforzado por normativa procesal que permita su correcta, \\ estricta y efectiva aplicación dentro de los procesos donde se discuten controversias de carácter \\ ambiental. Por lo que, con éste trabajo se buscar ofrecer un modelo procesal adecuado en el \\ marco del ordenamiento jurídico costarricense.
}

Palabras Claves: Derecho procesal ambiental, Proceso ambiental, Justicia ambiental.

\begin{abstract}
Environmental law needs to be reinforced by procedural regulations that allow its correct, strict and effective application in the judicial proceedings where environmental controversies are discussed. The objective of this paper is to offer an adequate procedural model that fits the Costa Rican legal system.
\end{abstract}

Keywords: Environmental procedural law, Environmental process, Environmental justice.

\footnotetext{
${ }^{1}$ Autor para correspondencia. Email mariopenachacon@gmail.com

2 Este artículo fue redactado dentro del Proyecto de Investigación denominado "El Proceso Ambiental", inscrito ante la Vicerrectoría de Investigación y el Instituto de Investigaciones Jurídicas de la Universidad de Costa Rica, bajo el código 722-B4-756.
} 


\section{Introducción}

Un Estado Social y Ambiental de Derecho está obligado a cumplir una serie de obligaciones procedimentales inherentes al disfrute de un medio ambiente sin riesgos, limpio, saludable y sostenible, entre ellas garantizarle a sus ciudadanos una justicia ambiental efectiva.

El derecho ambiental sustantivo necesita verse reforzado por normativa procesal que permita su correcta, estricta y efectiva aplicación dentro de los procesos donde se discuten controversias de carácter ambiental.

\section{Proceso Ambiental}

El derecho procesal ambiental, como parte integrante el derecho procesal social, busca otorgar el máximo de garantías procesales a individuos y grupos especialmente vulnerables, para la defensa de sus derechos subjetivos, intereses legítimos y en especial, de los derechos de incidencia colectiva o supraindividuales.

Para poder darle cumplimiento a lo anterior, los procesos ambientales deben ser céleres, expeditos, informales, de tramitación preferente y tutela expedita. Además, deben regirse por los principios generales del proceso, en especial por la oralidad, adquiriendo especial relevancia los de inmediatez, concentración, publicidad, itinerancia y gratuidad, en estricta armonía con las reglas constitucionales del debido proceso.

Debe evitarse el exceso de formalismos y todas aquellas actuaciones contrarias a la celeridad propia del proceso, sin demérito de la calidad de las decisiones judiciales, las cuales deben ajustarse a criterios de equidad y de derecho, así como a la búsqueda de la verdad real.

Su carácter finalista y evolutivo, la condición de derecho humano fundamental y la consolidación de sus principios generales, en especial los de participación, progresividad, no regresión, precautorio, contaminador-pagador y reparación integral, obligan un nuevo enfoque hermenéutico para el derecho ambiental sustantivo y procesal. La hermenéutica debe ser el punto de apoyo que permita arrancar al derecho ambiental de su estado de parálisis de efectividad, posicionándose en un instrumento procesal esencial e imprescindible para la tutela efectiva del medio ambiente.

Los órganos jurisdiccionales con competencias ambientales, deben conocer todas aquellas controversias originadas en las actividades y conductas humanas, activas $\mathrm{u}$ omisivas, de las autoridades públicas o de los particulares, cuyo efecto impacte negativamente la vida, la salud y el ambiente, los recursos naturales, la integridad de los ecosistemas, la biodiversidad, la belleza escénica y el Patrimonio Natural del Estado; teniendo como objeto la prevención de daños, la cesación de perjuicios actuales, la reposición de las cosas al estado anterior al menoscabo y el resarcimiento económico del daño producido.

Mientras no exista una jurisdicción ambiental especializada, toda controversia de índole ambiental es competencia exclusiva de la jurisdicción contencioso-administrativa, para ello sería ideal la creación de una nueva sección especializada del Tribunal Contencioso 
Administrativo. Como excepción a la regla anterior, los delitos contra la biodiversidad son juzgados en la jurisdicción penal; de igual modo, las controversias que se susciten entre particulares donde no medie acto u omisión administrativa, y que no involucren el dominio público, deben ser dilucidadas ante la jurisdicción agraria.

En materia de acceso a la justicia, lo ideal es que el esquema de legitimación procesal sea expandido a tal punto que, cualquier sujeto, en defensa del interés público ambiental, pueda plantear las acciones necesarias para alcanzar tal fin. Por ello, están legitimados para demandar, todos los sujetos que posean o invoquen la afección de intereses legítimos o derechos subjetivos, intereses supraindividuales, ejerzan la acción popular o cuando se vea amenazado o afectado el orden público ambiental. A la vez, organizaciones no gubernamentales, vecinales y cívicas deben estar facultadas para coadyuvar sin afectar la marcha y pretensión del proceso.

El principio de participación pública ambiental impone la obligación de habilitar la intervención de todos los sujetos con intereses en la materia, con carácter previo al dictado de las resoluciones y durante la realización de las audiencias; entre ellos deben contemplarse los terceros interesados, coadyuvantes y amicus curiae.

Es primordial facilitar el acceso de las personas a los tribunales, sin que la condición económica constituya un obstáculo que dificulte o impida la satisfacción de las pretensiones aducidas. Por ello, las instituciones procesales deben estructurarse de tal manera que el aspecto económico no tienda a alejar de los tribunales a los interesados y los fuerce a transar o negociar con la contraparte más fuerte económicamente, sino que les garantice sus derechos de accionar en defensa de sus intereses. A raíz de lo anterior, proponemos el patrocinio letrado gratuito especializado a favor de la parte procesal que litigue en pro del interés público ambiental, especialmente aquellos grupos en desventaja, siempre que carezca de recursos económicos suficientes. La gratuidad procesal también implica el litigio con exención de toda clase de timbres, sin obligación de aportar copias, rendir garantías o depósitos de dinero, así como ante las sentencias desestimatorias, implica la exoneración de costas a la parte vencida litigante de buena fe en defensa del interés de la colectividad. A los grupos en desventaja se les debe suministrar, además, canales apropiados en términos lingüísticos, culturales, económicos, espaciales y temporales; y asistencia en caso de dificultad de leer y escribir.

Los procesos para la tutela de intereses o derechos supraindividuales de carácter ambiental deben integrar todas aquellas reglas que permitan la acumulación de procesos, integración de intereses, comunicación de resoluciones, así como las particularidades propias de las sentencias, sus efectos y ejecución. Se propone, además, facultar al juzgador para reconocer una gratificación financiera a favor de la parte vencedora, cuando fuere una persona jurídica sin fines de lucro y su actuación hubiere sido relevante en la conducción y éxito de la acción colectiva.

Los procesos ambientales requieren un cambio en la genética de los jueces, quienes deben pasar de una posición clásica de neutralidad, pasividad, legalismo y formalismo, a convertirse en jueces proactivos, dinámicos, directores del proceso y jefes de la prueba; todo con el fin de asegurar y garantizar el interés público ambiental.

En la medida de lo posible, los procesos ambientales deben ser de conocimiento de jueces, jueces superiores, co-jueces o jueces supernumerarios especialistas en derecho ambiental. 
Con el fin de llegar a la verdad real, al juez ambiental se le deben reconocer amplios poderes-deberes, especialmente para interpretar y aplicar las normas procesales y sustantivas; declarar proceso de trámite preferente; determinar la legitimación activa para lograr la representación adecuada de los intereses comprometidos; admitir terceros dentro del proceso; adoptar medidas cautelares; ordenar las audiencias, informes, producción de pruebas pericial o científica; publicitar y comunicar los actos del proceso; establecer sanciones pecuniarias disuasivas y gratificaciones financieras; ejecutar la sentencia, debiendo ejercer facultades moldeadoras del proceso que permitan la mayor participación social y defensa efectiva del interés público ambiental, cumpliendo estrictamente con las reglas constitucionales del debido proceso y el derecho de defensa, sin perjuicio de su facultad para acelerar el trámite del proceso, mediante formas sencillas que se adapten a la naturaleza de la cuestión planteada.

En el proceso ambiental la conciliación, la transacción, el arbitraje y cualquier otro medio alternativo de solución de conflictos, deben ser utilizados como instrumentos de paz social con la finalidad de satisfacer y asegurar el interés colectivo ambiental. En todos los casos, el juzgador debe impulsar una actitud conciliadora, evitar el agravamiento de la contención de las partes, y encontrar solución satisfactoria a sus requerimientos, sin violentar los derechos indisponibles. La Administración Pública y las demás instituciones de derecho público están facultadas a conciliar, transar, someter a arbitraje y utilizar otros medios alternativos de solución de conflictos, siempre que no se contraríen normas de orden público.

El juez ambiental debe estar habilitado para disponer todas las medidas necesarias con el fin de ordenar, conducir o probar los hechos sometidos a valoración. En cualquier estado del proceso, aún con carácter de medida cautelar, podría solicitar medidas de urgencia, diligencias preliminares o preparatorias, e informes sumarios.

De oficio o a petición de parte, debería estar facultado para realizar investigaciones, solicitar documentos, pedir aclaraciones, visitar e inspeccionar el sitio de los hechos y evacuar prueba in situ. También podrá ordenar a las entidades públicas y a sus empleados rendir conceptos a manera de peritos, o aportar documentos u otros informes pertinentes en la causa de que se trate.

Independientemente de su sede, debe estar facultado para ejercer su función de forma itinerante, a fin de garantizar el acceso a la justicia, la disminución de costos y la búsqueda de la verdad real.

En los procesos ambientales la prueba posee especial importancia, requiriendo para su valoración, una alta especialización y conocimiento científico. Siendo la relación de causalidad el presupuesto más difícil de probar, la regla general deber ser la inversión de la carga probatoria. Los dictámenes emitidos por organismos especializados del Estado deben ostentar fuerza probatoria iuris tantum, sin perjuicio del derecho de las partes a su impugnación. Las pruebas deben apreciarse respetando el resultado del contradictorio, conforme a las reglas de la sana crítica racional.

En virtud de la trascendencia de la materia, las audiencias en los procesos ambientales deben gozar de un privilegio de prioridad con relación a otros tipos de procesos. Para ello, nuestra propuesta es un proceso que se desarrolle en dos audiencias, una preliminar y otra complementaria. La audiencia complementaria deberá ser oral y pública, y en la medida de lo posible, celebrarse en el sitio de afectación o donde acontecieron los hechos objeto de la controversia ambiental (in situ) y practicarse en el mismo acto, la 
inspección y cualquier otra clase de estudio de campo que requiera la participación de peritos y consultores técnicos, a fin de que el juez pueda aprovechar el asesoramiento del dictaminante y asegurarse que la pericia ha sido ejecutada a cabalidad.

En sentencia, deben fijarse las responsabilidades del caso y ordenarse la inmediata reparación integral del ambiente degradado, así como las medidas y acciones necesarias para evitar que se incremente el daño ambiental ocasionado, determinando claramente los parámetros, medidas de restauración y compensación y el plazo propuesto para el cumplimiento de las obligaciones del responsable, así como los mecanismos de control y verificación de su cumplimiento, y cuando sea procedente, el monto de la sanción pecuniario disuasiva y la devolución de la plusvalía ambiental obtenida de forma ilícita. Igualmente, debe cuantificarse y fijarse la indemnización por el daño ambiental acontecido, indicando expresamente la finalidad ambiental que debe atenderse, así como el órgano o entidad pública responsable de darle el destino señalado. La valoración económica del daño ambiental debe hacerse en forma integral, utilizando los métodos de valoración más apropiados para garantizar ese objetivo.

Se propone la creación de un fondo de restauración ambiental con el objeto de cubrir los costos de reparación de los daños que sean ocasionados al ambiente, además del pago de los estudios e investigaciones que el juez requiera realizar durante el proceso ambiental.

Con el fin de asegurar la celeridad del proceso y a la vez, impedir la dilación y el abuso procesal, nuestra propuesta es reducir el proceso ambiental a una única instancia de impugnación de sentencia ante un tribunal colegiado, garantizando el resultado final con una sola revisión por parte del órgano judicial jerárquicamente superior. La admisión de recursos contra resoluciones que ponen fin al proceso debe producir efectos meramente devolutivos, salvo cuando la fundamentación fuere relevante y pudiere resultar para la parte una lesión grave y de difícil reparación, caso en el cual el juez podría atribuir al recurso efectos suspensivos.

Si bien aún no encuentran respaldo normativo ni jurisprudencial en el sistema jurídico costarricense, se hace necesario empezar a cuestionarse la aplicación de sanciones pecuniarias con fines disuasivos y ejemplares, para daños ambientales graves y groseros, como complemento adecuado y accesorio a los principios contaminador pagador y reparación integral del ambiente.

Alcanzar un proceso ambiental efectivo y eficiente solo será posible a través del reforzamiento de la fase de ejecución de sentencia. Por ello, se hace imperativo que las sentencias y autos con dicho carácter, sean estrictamente acatadas, evitando todo tipo de actos que pretendan su desnaturalización, neutralización o paralización.

Por último y en virtud del deber de transparencia y rendición de cuentas, proponemos la creación de un registro de procesos ambientales de acceso público, donde se inscribirían los asuntos tramitados, el estado del proceso, los fallos emitidos y su cumplimiento, las condenas que recaigan sobre los demandados y el cumplimiento de las mismas. 


\section{Propuesta de Normas Modelo para el Proceso Ambiental en Costa Rica}

Tomando como insumos el documento preliminar de Acuerdo Regional sobre Acceso a la Información, Participación Pública y el Acceso a la Justicia en Asuntos Ambientales en América Latina y el Caribe; Código Modelo de Procesos Colectivos para Iberoamérica; la Propuesta de Ley Modelo de Daño Ambiental elaborada por el jurista argentino Néstor Cafferatta; la iniciativa de Ley de Acciones Colectivas de México; proyectos de ley costarricenses de Código Procesal Civil y Código Procesal Agrario; el anteproyecto de Ley de Jurisdicción Ambiental redactado por el exmagistrado costarricense Ricardo Zeledón Zeledón; la Ley Federal de Responsabilidad Ambiental de México y la Ley de Creación de los Tribunales Ambientales de Chile, así como la jurisprudencia procesal costarricense y las consideraciones anteriormente expuestas, procedemos a desarrollar una propuesta de norma modelo para el proceso ambiental costarricense.

\section{Norma Modelo para el Proceso Ambiental en Costa Rica}

Artículo 1. Definiciones. Para efectos de esta propuesta se entenderá por:

a) Amicus Curiae: Persona física o jurídica, no parte del proceso, con reconocida idoneidad técnica y profesional en la materia objeto del asunto sometido al conocimiento del tribunal, que invoque la protección de un interés público ambiental y que se encuentra facultada a presentar, por escrito y con patrocinio de abogado, opiniones con sus comentarios, observaciones o sugerencias.

b) Compensación ambiental: Toda afectación negativa a la diversidad biológica debe ser en primera instancia prevenida, corregida y mitigada, y únicamente en aquellos casos excepcionales donde ello no sea posible, compensada. La compensación ambiental consistirá en la inversión o las acciones que el responsable haga a su cargo, que generen una mejora ambiental, sustitutiva de la reparación total o parcial del daño ocasionado al ambiente, según corresponda, y equivalente a los efectos adversos ocasionados por el daño. Dicha inversión o acciones deberán hacerse en el ecosistema o región ecológica en donde se hubiese ocasionado el daño. De resultar esto materialmente imposible, la inversión o las acciones se llevarán a cabo en un lugar alternativo, vinculado ecológica y geográficamente al sitio dañado y en beneficio de la comunidad afectada.

c) Consultores técnicos: Expertos consultores en una ciencia, arte o técnica que ayudan al juzgador a entender y valorar la prueba altamente científica o técnica. El consultor técnico está facultado a presenciar las operaciones periciales y acotar observaciones durante su transcurso, sin emitir dictamen. A la vez, durante las audiencias, las partes pueden acompañarse de un consultor técnico para que las auxilie en los actos propios de su función.

d) Contaminación ambiental: Presencia de elementos o agentes en niveles, concentraciones y permanencia tales, que puedan perjudicar el equilibrio de los ecosistemas y con ello la vida, la flora o fauna o degradar la calidad del agua, del suelo, 
la atmósfera o de los bienes y recursos naturales en general y/o amenacen o representen un peligro para la seguridad y salud humana, animal, vegetal o del ambiente.

e) Criterio de equivalencia: Lineamiento obligatorio para orientar las medidas de reparación y compensación ambiental, que implica restablecer los elementos y recursos naturales o servicios ambientales por otros de las mismas características.

f) Daño ambiental: Toda acción, omisión, comportamiento u acto lícito o ilícito, ejercido por un sujeto físico o jurídico, público o privado, que altere, menoscabe, trastorne, disminuya o ponga en peligro inminente y significativo, alguno de los elementos constitutivos del ambiente, rompiéndose con ello el equilibrio propio y natural de los ecosistemas y sus principios rectores de autorregulación y auto perpetuación. El daño ambiental puede manifestarse de manera continuada o permanente, progresiva o crónica, sobrevenida y por sinergia. El concepto daño ambiental comprende:

- daño ambiental una vez consumado, la etapa anterior al daño (pre-daño) que incluye el riesgo, la amenaza y peligro ambiental;

- daño ambiental de incidencia colectiva y el daño ambiental individual;

- daño ambiental patrimonial y extra patrimonial, en sus dos vertientes, colectiva e individual.

g) Daño ambiental colectivo: También conocido como daño ambiental puro, es aquel que recae sobre bienes ambientales de incidencia colectiva, de naturaleza común y que implica daño al ambiente en sí mismo. Se trata de un daño al hábitat y a la calidad de vida y que reviste naturaleza transindividual, impersonal e indiferenciada por su carácter difuso. Es toda alteración negativa relevante del ambiente, sus recursos, el equilibrio de los ecosistemas, de los bienes o valores colectivos ambientales.

h) Daño ambiental individual o daños a través del ambiente: Daño a la persona (física o jurídica, pública o privada) y sus bienes (incluso bienes ambientales susceptibles de apropiación privada) por alteración del medio ambiente, y que ataca $\mathrm{y}$ pone en riesgo, derechos subjetivos e intereses legítimos, dando derecho al resarcimiento o indemnización, y a la adopción de medidas preventivas al sujeto damnificado, víctima u ofendido directo.

i) Daño moral colectivo de carácter ambiental o daño ambiental extra patrimonial: Disminución en la tranquilidad anímica y espiritual que sufre la colectividad en su conjunto, equivalente a la lesión a intereses colectivos no patrimoniales, causada por el daño acontecido contra el entorno natural que los circunda.

j) Estado base: Condición en la que se habrían hallado los hábitats, los ecosistemas, los elementos y recursos naturales, las relaciones de interacción y los servicios ecosistémicos, en el momento previo inmediato al daño y de no haber sido este producido. Se determinará a partir de la mejor información disponible al momento de su valoración.

k) Fondo de Restauración Ambiental: Fondo creado con el objeto de cubrir los costos de la reparación de los daños que sean ocasionados al ambiente, además del pago de los estudios e investigaciones que el juez requiera realizar durante el proceso ambiental.

l) Gratificación financiera: Gratificación económica, otorgada por el tribunal a favor persona jurídica sin fines de lucro, en procesos para la tutela de intereses 
supraindividuales, cuando su actuación hubiere sido relevante en la conducción y éxito de la acción colectiva.

m) Grupos en desventaja: Personas y grupos de personas que tienen mayor probabilidad de no conocer los riesgos relacionados al medio ambiente al cual están sujetos, o de no ejercer plenamente sus derechos de acceso incluidos, entre otros, las mujeres, los pueblos indígenas, los afrodescendientes, las personas adultas mayores, los niños, los jóvenes, las personas con discapacidad, en situación de vulnerabilidad por condiciones de discriminación, pobreza, analfabetismo, falta de dominio del idioma o idiomas oficiales, salud o cualquier otra condición.

n) Intereses supraindividuales o de incidencia colectiva: Intereses difusos, intereses estrictamente colectivos e intereses individuales homogéneos.

o) Intereses difusos: Intereses transindividuales, de naturaleza indivisible, de que sean titulares personas indeterminadas y ligadas por las mismas circunstancias de hecho.

p) Intereses colectivos: Intereses transindividuales, de naturaleza indivisible de los que sea titular un grupo, categoría o clase de personas determinadas o fácilmente determinables ligadas entre sí o con la parte contraria por una relación jurídica base.

q) Intereses individuales homogéneos: Así entendidos los provenientes de origen común.

r) Plusvalía ambiental ilícita: Ganancia, beneficio o provecho económico obtenido de forma ilícita a través de un acto u omisión que genere daño ambiental.

s) Registro de procesos ambientales: Registro judicial de acceso público donde se inscriben los procesos judiciales ambientales tramitados, el estado del proceso, los fallos emitidos y su cumplimiento, condenas que recaigan sobre los demandados y cumplimiento de las mismas.

t) Reparación ambiental: Prioritariamente se persigue la reparación primaria, también conocida como reparación in situ, consistente en toda medida correctora que restituya o aproxime al máximo, los recursos naturales o servicios de recursos naturales dañados a su estado base. Si la reparación primaria no da lugar a la restitución del medio ambiente a su estado base, se efectuará una reparación complementaria consistente en aportar mejoras adicionales al ecosistema degradado, ya sea en el lugar dañado o en un lugar alternativo. Además, se efectuará una reparación compensatoria para compensar las pérdidas provisionales de recursos naturales o servicios de recursos naturales que tengan lugar desde la fecha en que se produjo el daño hasta el momento en que la reparación primaria haya surtido todo su efecto. La reparación de daños ambientales supone, asimismo, eliminar toda amenaza significativa de que se produzcan efectos desfavorables para la salud humana.

u) Riesgo y amenaza ambiental: El riesgo ambiental comprende la capacidad real o potencial, cierta o incierta, de una acción u omisión que genera la posibilidad de causar daño ambiental. Cuando el riesgo es inminente se entiende que la situación es de peligro o amenaza ambiental o peligro ambiental que constituye una probabilidad suficiente o inminente de que se produzca daños en un futuro próximo. Tanto el riesgo como la amenaza ambiental forman parte del concepto global de daño ambiental.

v) Sanción pecuniaria disuasiva: Pago impuesto por la autoridad judicial para penalizar una conducta ilícita dañosa y dolosa con la finalidad de lograr una prevención 
general y especial e inhibir en el futuro comportamientos prohibidos. Es accesoria a la reparación o compensación del daño ocasionado al ambiente y tendrá como objetivo neutralizar el beneficio económico obtenido, si los hubiere, y garantizar prioritariamente el monto de las erogaciones del actor o actores que hayan sido necesarias para acreditar la responsabilidad.

w) Servicios ecosistémicos: Las funciones que desempeña un elemento o recurso natural en beneficio de otro elemento o recurso natural, los hábitats, ecosistema o sociedad.

Artículo 2. Principios Procesales. El proceso ambiental se rige por los principios generales del proceso, en especial el de oralidad. Aplicarán la inmediatez, concentración, publicidad, itinerancia y gratuidad, en estricta armonía con las reglas constitucionales del debido proceso y el derecho de defensa. Se actuará con buena fe procesal.

Se evitará el exceso de formalismos y todas aquellas actuaciones contrarias a la celeridad propia del proceso, sin demérito de la calidad de las decisiones judiciales, las cuales deben ajustarse a criterios de equidad y de derecho, así como la búsqueda de la verdad real.

Deberán aplicarse criterios que garanticen el interés público ambiental mediante el mantenimiento del equilibrio ecológico, la eficiencia económica y la equidad social entre las existentes y futuras generaciones; así como los principios rectores reconocidos en el ordenamiento jurídico internacional y nacional para la tutela del ambiente, entre ellos: participación, progresividad, no regresividad, prevención, precaución, contaminador-pagador y reparación integral.

Artículo 3. Interpretación. Al interpretar las normas procesales, los tribunales deberán considerar su carácter instrumental, atendiendo fundamentalmente a su espíritu y finalidad. Para ello, se tomará en cuenta el sentido propio de sus palabras, en relación con el contexto, los antecedentes históricos y la realidad social del momento en que han de ser aplicadas. Además, debe tomarse en consideración el carácter finalista y evolutivo del derecho ambiental, su condición de derecho humano fundamental, así como sus principios rectores. En caso de duda respecto al alcance de las disposiciones legales en materia ambiental se aplicarán en el sentido más favorable a la protección de la naturaleza.

Artículo 4. Integración. En ausencia o insuficiencia de norma procesal expresa se deberán aplicar las disposiciones legales que rijan situaciones análogas, los usos y las costumbres, los principios generales del derecho, así como la doctrina, atendiendo a las circunstancias.

Procede la aplicación supletoria de otras normas procesales que ofrezcan soluciones más céleres al proceso, siempre que se respeten los principios que rigen el debido proceso y el derecho de defensa, y únicamente ante ausencia o insuficiencia de una norma expresa.

Artículo 5. Papel del juez ambiental. Siempre que sea posible, los procesos ambientales serán de conocimiento de tribunales especializados conformados por jueces, jueces superiores, co-jueces o jueces supernumerarios especialistas en derecho ambiental. 
Con el fin de llegar a la verdad real, el juez dispondrá de amplios poderes-deberes, en especial respecto de interpretar y aplicar las normas procesales y sustantivas; declarar proceso de trámite preferente; determinar la legitimación activa para lograr la representación adecuada de los intereses comprometidos; admitir terceros dentro del proceso; adoptar medidas cautelares; ordenar las audiencias, informes, producción de pruebas pericial o científica; publicitar y comunicar los actos del proceso; establecer sanciones pecuniarias disuasivas y gratificación financiera; ordenar la devolución de la plusvalía ambiental ilícita: ejecutar la sentencia, debiendo ejercer facultades moldeadoras del proceso que permitan la mayor participación social y defensa efectiva del interés público ambiental, cumpliendo estrictamente con las reglas constitucionales del debido proceso y el derecho de defensa, sin perjuicio de su facultad para acelerar el trámite del proceso, mediante formas sencillas que se adapten a la naturaleza de la cuestión planteada.

En todos los casos, el juzgador deberá impulsar una actitud conciliadora, evitar el agravamiento de la contención de las partes, y encontrar solución satisfactoria a sus requerimientos, sin violentar los derechos indisponibles. Para lograr dicho objetivo, pondrá en aplicación los principios propios de la resolución alternativa de conflictos: accesibilidad, protección al derecho de las partes, eficiencia, justicia, equidad, confianza, validez y eficacia de la decisión. En estos términos llevará a cabo las audiencias que fueran necesarias para lograr una solución parcial o total del conflicto.

El juez podrá disponer todas las medidas necesarias para ordenar, conducir o probar los hechos sometidos a valoración. En cualquier estado del proceso, aún con carácter de medida cautelar, podrá ordenar medidas de urgencia, diligencias preliminares o preparatorias, e informes sumarios.

De oficio o a petición de parte, está facultado a realizar investigaciones, solicitar documentos, pedir aclaraciones, visitar e inspeccionar el sitio de los hechos y evacuar prueba in situ. También podrá ordenar a las entidades públicas y a sus empleados rendir conceptos a manera de peritos, o aportar documentos u otros informes pertinentes en la causa de que se trate.

Independientemente de su sede, debe ejercer su función de forma itinerante, a fin de garantizar el acceso a la justicia, la disminución de costos y la búsqueda de la verdad real.

Podrá actuar en días y horas inhábiles cuando la dilación pueda causar perjuicio grave a los interesados o al medio ambiente, entorpecer el proceso o hacer ilusorio el efecto de la sentencia.

Cuando en sentencia determine la existencia de daño ambiental ordenará su recomposición y establecerá los mecanismos de control y fiscalización para su efectivo cumplimiento. Cuando la parte ganadora no inste la restauración del ambiente dañado, podrá, de oficio, ordenarla en ejecución de sentencia.

Podrá extender su fallo a cuestiones no sometidas expresamente a su consideración por las partes, supliendo las falencias de las alegaciones de las mismas y cumpliendo con ello, el deber de garantizar el interés público ambiental.

Cuando de los hechos de la demanda deduzca a priori, la posible comisión de un delito ambiental, deberá dar inmediato aviso al Ministerio Público. 
Artículo 6. Competencia. Los tribunales ambientales se irán creando, en forma progresiva, en las ciudades más cercanas a la problemática ambiental, y en San José. Es competente el juez del lugar donde hubiera ocurrido o pudiera ocurrir el daño, o donde se dio la trasgresión al orden público ambiental cuando sea de ámbito local; mientras que para afectaciones de carácter regional o nacional será competente el tribunal ambiental ubicado en San José.

Mientras no exista una jurisdicción especializada, toda controversia de índole ambiental será competencia exclusiva de la jurisdicción contencioso administrativa por medio de una sección especializada en la materia, dentro del Tribunal Contencioso Administrativo. Como excepción a la regla anterior, los delitos contra la biodiversidad serán juzgados en la jurisdicción penal; de igual modo, las controversias que se susciten entre particulares, donde no medie acto u omisión administrativa, ni del dominio público, serán competencia de la jurisdicción agraria.

Los órganos jurisdiccionales con competencias ambientales conocerán todas aquellas controversias originadas en las actividades y conductas humanas de acción u omisión de las autoridades pública o de los particulares, cuyo efecto impacte negativamente la vida, la salud y el ambiente, los recursos naturales, la integridad de los ecosistemas, la biodiversidad, la belleza escénica y el patrimonio natural del Estado. Tendrá como objeto la prevención de daños, la cesación de perjuicios actuales, la reposición de las cosas al estado anterior al menoscabo y el resarcimiento económico del daño producido.

Artículo 7. Gratuidad procesal. Se litigará con exención de toda clase de timbres, sin obligación de aportar copias, rendir garantías o depósitos de dinero, con las excepciones expresamente dispuestas en la legislación especial.

Si es necesario publicar una resolución, edicto o aviso, las partes tendrán derecho a elegir si lo hacen en un diario de circulación nacional, o en forma gratuita en el Boletín Judicial, salvo disposición expresa en contrario.

Si es posible, de oficio, se remitirá electrónicamente copia de la resolución y en su caso, del edicto o aviso, al ente encargado de la publicación. Caso contrario, a solicitud de parte, se emitirá la copia, debidamente sellada, para su diligenciamiento.

Artículo 8. Asistencia técnica y patrocinio legal gratuito. La parte procesal que litigue a favor del interés público ambiental, especialmente aquellos grupos en desventaja, tendrán acceso a asistencia técnica y patrocinio legal gratuito especializado, siempre que carezca de recursos económicos suficientes. La posibilidad de disponer de este beneficio, deberá informarse en la resolución que dé curso al proceso. La parte interesada deberá pedirlo directamente en las oficinas de la Defensa Pública de cada circuito judicial.

Si se acredita que quien solicita la defensa técnica tiene recursos económicos suficientes para sufragar el costo de la asesoría legal, dicha dependencia requerirá su pago, a través de los mecanismos legales pertinentes.

A los grupos en desventaja se les suministrará además canales apropiados en términos lingüísticos, culturales, económicos, espaciales y temporales; y asistencia en caso de dificultad para leer y escribir.

Artículo 9. Abuso procesal y proceso fraudulento. Cuando el juzgador estime, de acuerdo con el resultado del proceso y la valoración probatoria, que una parte actuó con temeridad, mala fe o abuso en el ejercicio de los derechos procesales, lo declarará en 
sentencia. Podrá hacerlo de manera anticipada cuando existan elementos suficientes para ello. En cualquier momento en que, por las circunstancias del caso concreto, el juez esté convencido del uso de un proceso para practicar un acto simulado o conseguir un móvil prohibido por la ley, dictará sentencia que impida a las partes obtener sus objetivos.

Si una parte incurre en alguna de las faltas contempladas, el juzgador aplicará el régimen disciplinario sobre las partes y sus abogados, sancionando cualquier acto contrario a la dignidad de la justicia, la buena fe, la lealtad, la probidad; así como cualquier forma de abuso y fraude procesal. También cuando se compruebe que han realizado gestiones o han asumido actitudes dilatorias o litigado con temeridad. Según la gravedad de la conducta, el juez aplicará las amonestaciones y multas que correspondan y pondrá a la orden de la autoridad respectiva para su juzgamiento cuando pudiera constituir delito, contravención o falta.

Además, podrá condenarse a quien sea responsable, al pago de daños, perjuicios y costas, los cuales se liquidarán en proceso de ejecución. Cuando sea evidente que quien haya asesorado legalmente a las partes, tenía conocimiento de la situación, se pondrá en conocimiento al colegio profesional respectivo.

Artículo 10. Actividad procesal defectuosa. Solo se declararán nulidades cuando sea absolutamente necesaria para garantizar el debido proceso, derecho de defensa o impedir la infracción a cualquier otro derecho fundamental. Toda actividad defectuosa es susceptible de saneamiento, mientras no involucre un vicio esencial.

Cuando sea imprescindible la declaratoria de nulidad, se conservarán todas las actuaciones que en sí mismas no se vean afectadas por la invalidez. La nulidad total o parcial de un acto no conlleva la de las actuaciones que fueren independientes de aquel, ni impide que lo conservado produzca efectos legales, salvo disposición en contrario.

Artículo 11. Incidentes. Los incidentes no suspenden el proceso principal, salvo que la ley les conceda ese efecto de modo expreso, si es imposible continuar el procedimiento o cuando el tribunal lo disponga al resultar indispensable para su adecuado desarrollo.

Artículo 12. Acceso al expediente. Todo alegato escrito o documento incorporado al expediente, con las excepciones de ley, será de acceso a las personas que figuren como partes, abogadas y a quienes el ordenamiento jurídico autorice. Se pondrán a disposición de las personas usuarias los mecanismos necesarios, a fin de que la consulta del expediente físico o electrónico, sea efectiva.

En aquellos casos que dentro del expediente judicial conste información de interés público y general que no se encuentre en ninguna base de datos, archivo o registro de la Administración Pública, el juzgador permitirá el acceso de dicha información a cualquier ciudadano que lo solicite, reservándose concomitantemente, el resto del expediente.

Las sentencias y acuerdos conciliatorios homologados serán públicos.

Artículo 13. Legitimación activa. En el proceso ambiental están legitimados para demandar, quienes tengan o invoquen la afección de intereses legítimos o derechos subjetivos, intereses supraindividuales, ejerzan la acción popular o cuando se vea amenazado o afectado el orden público ambiental. 
Los intereses difusos podrán ser reclamados por cualquier ciudadano, organización representativa o institución pública dedicada a su defensa, en interés de la colectividad.

Los intereses colectivos, podrán ser reclamados por las organizaciones legalmente constituidas que tengan por objeto la defensa o protección de esos intereses y los propios grupos afectados. Cuando exista concurrencia de grupos u organizaciones el tribunal decidirá a quién tendrá por legitimado, tomando en cuenta su representatividad. Se podrá establecer el orden en que las restantes organizaciones o grupos podrán sustituir al que el tribunal le reconoció legitimación. Los perjudicados directos conservan su legitimación individual.

Los intereses individuales homogéneos podrán ser reclamados por cualquier miembro del grupo.

Artículo 14. Legitimación pasiva. La legitimación pasiva en un proceso ambiental podrá recaer sobre persona física o jurídica, pública o privada, entre ellos:

La Administración Pública Centralizada o Descentralizada autora de la conducta u omisión administrativa dañina del ambiente.

Los órganos administrativos con personalidad jurídica instrumental, en tanto sean autores de la conducta u omisión administrativa objeto del proceso, conjuntamente con el Estado o el ente al que se encuentren adscritos.

Las personas físicas o jurídicas que hayan derivado derechos e intereses legítimos de la conducta u omisión administrativa objeto del proceso.

Cualquier otra persona física o jurídica que haya sido llamada al proceso como responsable.

Artículo 15. Intervención de terceros. Un tercero podrá intervenir en un proceso, sin alegar derecho alguno, solo con el fin de coadyuvar a la victoria de una parte, por tener un interés jurídico propio en el resultado.

El coadyuvante no podrá pedir nada para sí, ni podrá cambiar la pretensión a la que coadyuva; pero podrá hacer todas las alegaciones de hecho y derecho, así como usar todos los recursos y medios procesales para hacer valer su interés, excepto en lo que perjudique al coadyuvado. La sentencia es susceptible de repercutirle positiva o negativamente.

Podrán coadyuvar en estos procesos, sin afectar su marcha y pretensión, las organizaciones no gubernamentales, las vecinales, cívicas o de índole similar.

También son considerados partes del proceso los terceros que intervengan con pretensiones propias respecto de la conducta objeto del proceso y quienes sean llamados, de oficio o a instancia de parte, en calidad principal o accesoria. $\mathrm{Su}$ participación puede hacerse valer en cualquier momento antes del dictado de la sentencia, y tomarán el proceso en el estado en el que se encuentre, siempre que ello no sirva para burlar los plazos de caducidad.

Cualquier persona, física o jurídica, que no sea parte en el proceso, que posea reconocida idoneidad técnica y profesional en la materia objeto del asunto sometido al conocimiento del tribunal y que invoque la protección de un interés público ambiental, podrá presentar, por escrito y con patrocinio de abogado, una opinión con sus comentarios, observaciones o sugerencias. La entrega de la opinión escrita no 
suspenderá, ni alterará la tramitación del proceso, pero el tribunal deberá considerarla en la sentencia definitiva.

La presentación de la opinión escrita no conferirá a quien la haya emitido la calidad de parte, ni le otorgará ninguna posibilidad de actuación adicional en el proceso.

Artículo 16. Consultores técnicos. Cualquiera de las partes podrá solicitar la asistencia de un consultor en una ciencia, arte o técnica, el cual decidirá sobre su designación, según las reglas aplicables a los peritos, sin que por ello asuman tal carácter.

El tribunal podrá citar a un consultor, para efectos de ilustración y, excepcionalmente, podrá autorizarlo para que interrogue a los peritos y testigos durante las audiencias.

El consultor técnico podrá presenciar las operaciones periciales y acotar observaciones durante su transcurso, sin emitir dictamen; además, se dejará constancia de sus observaciones.

También, durante la audiencia las partes podrán tener a un consultor, para que las auxilie, en los actos propios de su función.

Artículo 17. Litispendencia y acumulación de procesos. Tratándose de procesos para la tutela de intereses supraindividuales, la primera acción colectiva produce litispendencia respecto de las demás acciones colectivas, aun siendo diferente el legitimado activo. Una acción colectiva, produce litispendencia en relación con cualquier otra pretensión individual posterior, aunque no exista identidad subjetiva.

Establecido un proceso para la tutela de intereses supraindividuales, todos los procesos anteriores y futuros originados en la misma causa, se acumularán a éste cuando proceda. Para tal efecto, los demás órganos jurisdiccionales, en cuanto tengan conocimiento de la existencia de un proceso de tutela de intereses supraindividuales, deben remitir los expedientes y comunicar a todos los interesados su derecho a apersonarse en el proceso ya establecido.

Artículo 18. Integración de intereses supraindividuales. A solicitud de quien pretenda iniciar un proceso para la tutela de intereses supraindividuales, con la finalidad de concretar a los integrantes del grupo afectados que sean fácilmente determinables, el juzgador debe adoptar las medidas que sean necesarias de acuerdo con las circunstancias y los datos suministrados por el solicitante. El juzgador podrá requerir al futuro demandado para que colabore en esa determinación. En la solicitud se expresarán los fundamentos, con indicación del objeto del proceso que se quiere preparar.

Artículo 19. Comunicaciones y notificaciones en procesos de intereses supraindividuales. Tratándose de reclamos sobre intereses difusos, la admisión de la demanda se publicará en un diario de circulación nacional o mediante cualquier otro medio de comunicación que se estime idóneo. Además, se colocará un aviso en un lugar público de la zona o sector involucrado, si fuere procedente. Para efectos de este artículo se entenderá hecha la comunicación el día de la publicación. Una vez transcurrido el plazo, no se permitirá la intervención individual de interesados, sin perjuicio de que estos puedan hacer valer sus derechos en ejecución de la sentencia que se dicte en el proceso.

Cuando se trate de procesos colectivos en el que estén determinados o sean fácilmente determinables los interesados o en los individuales homogéneos, el demandante deberá 
comunicar a los demás interesados su intención de interponer la acción. Las comunicaciones deberán practicarse en el mes anterior a la presentación de la demanda y necesariamente se consignará en ella el tribunal al que se presentará y su contenido. Cuando la comunicación no sea posible, en la demanda se deberán consignar los datos de identificación de tales afectados, quienes serán informados de la presentación de la demanda por medio de un edicto en un diario de circulación nacional o mediante cualquier otro medio de comunicación que se estime idóneo. Cuando la notificación se practique directamente, el plazo para hacer valer los derechos corre a partir del día de la presentación de la demanda. Cuando se ponga en conocimiento por edicto, el plazo iniciará el día siguiente al de la publicación. Tras la comunicación y vencido el plazo, el interesado podrá intervenir en cualquier momento en el proceso, pero sólo podrá realizar los actos procesales que no hubieran precluido.

Los avisos y edictos deberán publicarse en el Boletín Judicial, en un diario de circulación nacional o mediante otro medio de comunicación colectiva que se estime idóneo por el tribunal.

Artículo 20. Demanda. La demanda contendrá la indicación de los hechos, actos, acciones u omisiones que la motivan; la enunciación de las pretensiones; el nombre del o de los demandados, personas físicas o morales, públicas o privadas, responsable de la amenaza o del agravio, así como su domicilio; las pruebas que pretenda hacer valer y el nombre y firma del actor.

Tratándose de intereses supraindividuales, deberá indicarse además el derecho o interés del grupo amenazado o vulnerado, estimado de daños que se hubiere producido o se pueden producir, si hay sujetos individuales, si existen otros grupos afectados o que tiendan a la protección de lo reclamado y contener una relación circunstanciada de las personas, tiempo y lugar donde se produjo el hecho u omisión.

Respecto de los intereses públicos se podrá darles intervención a las instituciones públicas en todos los asuntos de su interés directo, respeto de derechos económicos, sociales, culturales o públicos propios de su competencia. También a la Defensoría de los Habitantes cuando haya un interés nacional.

Para su admisibilidad, será necesario acreditar la adecuada representatividad de la persona legitimada y la relevancia social de la tutela colectiva, caracterizada según la naturaleza del bien jurídico, por las particularidades de la lesión o por el número de personas alcanzadas. Cuando se trate de un reclamo de intereses individuales homogéneos, deberá demostrarse el predominio de las cuestiones comunes sobre las individuales y la utilidad de la tutela colectiva en el caso concreto. El juzgador podrá ordenar la práctica de pruebas y audiencias necesarias para la verificación de tales presupuestos. Deberán tomarse las previsiones para que estas se realicen en un lugar idóneo, que facilite la asistencia de las personas convocadas.

La demanda se dirigirá contra el presunto responsable del hecho u omisión que la motiva, si fuere conocido. No obstante, cuando en el curso del proceso se establezca que existen otros posibles responsables, el juez, de oficio ordenará su citación en los términos legales a que haya lugar.

Artículo 21. Excepciones y defensas previas. Las excepciones y defensas previas deberán oponerse al contestar la demanda y se resolverán durante la audiencia preliminar, salvo la de incompetencia. La de prescripción, así como transacción, conciliación, cosa juzgada, acuerdo arbitral y caducidad, se acogerán en la audiencia 
preparatoria, cuando sean evidentes o manifiestas. De lo contrario, se resolverán en la sentencia.

Artículo 22. Medios alternativos de solución de conflictos. En todos los casos, el juzgador deberá impulsar una actitud conciliadora, evitar el agravamiento de la contención de las partes, y encontrar solución satisfactoria a sus requerimientos, sin violentar los derechos indisponibles. Para lograr dicho objetivo y siempre que no implique renuncia al derecho de acceder a la justicia ambiental, pondrá en aplicación los principios propios de la resolución alternativa de conflictos de accesibilidad, protección al derecho de las partes, eficiencia, confianza, justicia y equidad, validez y eficacia de la decisión, llevará a cabo las audiencias que fueran necesarias para lograr una solución, parcial o total, del conflicto.

La Administración Pública y las demás instituciones de Derecho Público están facultadas a conciliar, transar, someter a arbitraje y utilizar otros medios alternativos de solución de conflictos, siempre que no se contraríen normas de orden público.

De alcanzarse un acuerdo total, se levantará un acta donde se indicarán todos sus extremos y se procederá a su homologación por parte del juez, el cual deberá siempre cerciorarse que lo acordado no sea contrario al orden público ambiental, velando, en todo momento para que se cumpla con la obligación de recomposición del ambiente degradado, en la medida de lo posible, a su estado base.

El acuerdo conciliatorio homologado, tendrá los mismos efectos de la sentencia y producirá el archivo del expediente, una vez que el juzgador compruebe el total cumplimiento de lo acordado.

La conciliación es admisible en todo proceso donde se discutan intereses supraindividuales. La propuesta de acuerdo debe ser debidamente comunicada por el representante a todos los interesados. De ser necesario, lo hará mediante la publicación de un edicto. En la audiencia en que se intente la conciliación, el representante deberá demostrar que comunicó la propuesta de acuerdo a los interesados y que dicha propuesta fue aprobada por al menos dos terceras partes de los interesados. Aceptada la propuesta, si no fuere contraria a derecho o evidentemente lesiva de los derechos de la minoría, el tribunal la homologará y surtirá efectos, incluso respecto de quienes disintieron o no se manifestaron.

Artículo 23. Conclusión anticipada del proceso. Se podrá concluir anticipadamente el proceso por medio del desistimiento, la renuncia del derecho, la deserción, imposibilidad sobrevenida y la satisfacción extraprocesal, salvo que se trate de bienes indisponibles o de dominio público.

Artículo 24. Tutela cautelar. Ante daños ambientales de difícil o imposible reparación, el juzgador de oficio o a solicitud de parte y en cualquier estado del proceso, podrá dictar medidas cautelares para asegurar y proteger los recursos naturales y el equilibrio ecológico, impedir la eventual comisión del daño o que las acciones u omisiones dañinas continúen.

Las medidas cautelares podrán contener la conservación del estado de cosas, o bien, efectos anticipativos o innovativos, siendo que el juzgador podrá imponerle, provisionalmente, a cualquiera de las partes del proceso, obligaciones de hacer, de no hacer o de dar. 
En casos calificados, a criterio del juez, cuando exista un peligro inminente, o se cause un daño irreparable, lo cual justificará en resolución considerada, la medida cautelar se decretará sin notificación ni audiencia previa y podrá ejecutarse en forma inmediata.

El juzgador tendrá facultades para determinar el alcance de las medidas, así como su modificación, sustitución o cese. Para imponer, otorgar o denegar alguna medida cautelar, el juez deberá considerar las reglas unívocas de la ciencia y de la técnica, los principios elementales de justicia, lógica, conveniencia, y especialmente el principio precautorio y el de proporcionalidad, ponderando la eventual lesión al interés público ambiental respecto a los daños y los perjuicios provocados con la medida a las partes o terceros en sus derechos subjetivo y/o intereses legítimos.

Cuando varíen las circunstancias de hecho, que motivaron la adopción de alguna medida cautelar, el juez de oficio o a instancia de parte, podrá modificarla o suprimirla. En igual forma, cuando varíen las circunstancias de hecho que dieron motivo al rechazo de la medida solicitada, el juzgador, de oficio o a instancia de parte, podrá considerar nuevamente la procedencia de aquella $\mathrm{u}$ otra medida cautelar.

En situaciones de excepción, y siempre que no se ponga en peligro el interés público ambiental, a solicitud de parte, el juez podrá sustituir la medida cautelar por otra equivalente, previa valoración económica provisional del eventual daño ambiental que garantice su recomposición en la medida de lo posible a su estado base. La caución real se constituirá con depósito de dinero, valores cotizables o con el otorgamiento de prendas o hipotecas, por la cantidad que el juzgador determine.

Para la efectiva tutela cautelar ambiental, además de las disposiciones generales de las medidas cautelares, se aplicarán las siguientes reglas:

- La tutela cautelar para la protección de los recursos, bienes y servicios ambientales, procederá, aunque la demanda o la contestación no cumplan con los requisitos de forma para su admisibilidad, excepto si están relacionados con las pretensiones.

- El tribunal podrá requerir se rinda una garantía económica, o bien disponer cualquier otro tipo de obligación de índole no dineraria, cuando algunas de estas sean necesarias para la efectiva ejecución de la medida.

- A fin de determinar la procedencia de la medida y para su ejecución, sin necesidad de requerimiento de parte, el juez podrá gestionar la información que considere necesaria y ordenar de urgencia, cuando sea procedente, un reconocimiento judicial. Podrá ordenar experticias y auxiliarse con personas funcionarias públicas o consultoras técnicas.

- La falta de certeza científica o técnica no podrá ser justificante para dejar de adoptar la tutela cautelar.

- Cuando se adopten las medidas tutelares para evitar la amenaza o agravamiento de algún daño ambiental, se harán las prevenciones pertinentes para su cumplimiento, a la persona dueña del bien o poseedora por cualquier título, la construcción o la plantación, si está presente en el acto. Si no se encuentra, la prevención se hará a quien ejerza la dirección, administración o a la persona encargada, operaria, trabajadora, que posea o habite el lugar por encargo de otra, para que de inmediato suspenda las actividades, con el apercibimiento de que, en caso de incumplimiento, se le investigará por el delito de desobediencia a la autoridad. Los terceros propietarios o poseedores de los inmuebles en los que se haya ocasionado el daño estarán obligados a permitir las medidas precautorias que resuelva el órgano 
jurisdiccional. En todo caso tendrán derecho de repetir respecto a la persona que resulta responsable de ocasionar dichos daños.

- Para asegurar el resultado del procedimiento y la recomposición del ambiente dañado, el tribunal dispondrá la anotación de oficio al margen de la inscripción del bien o bienes sobre los cuales recae la denuncia de daño ambiental, en el registro respectivo. Tal anotación estará exenta del pago de derechos.

Artículo 25. Prueba. De oficio o a petición de parte, el juzgador ordenará y practicará todas las diligencias de prueba necesarias, para determinar la verdad real de los hechos relevantes en el proceso. Los medios de prueba podrán ser todos los que estén permitidos por el Derecho público y el Derecho común. Las pruebas podrán ser consignadas y aportadas al proceso, mediante cualquier tipo de soporte documental, electrónico, informático, magnético, óptico, telemático o producido por nuevas tecnologías.

Las pruebas se apreciarán en su totalidad, respetando el resultado del contradictorio, conforme a criterios de la lógica, experiencia y ciencia que informan el correcto entendimiento humano; salvo texto legal que expresamente disponga una regla de apreciación diversa.

Deberán expresarse los fundamentos fácticos, jurídicos y de equidad de las conclusiones y las razones por las cuales se les ha conferido mayor o menor valor a unas u otras pruebas.

La carga de la prueba de la ausencia de contaminación, degradación o afectaciones no permitidas, corresponderá a quien se le acuse de haber ocasionado daño ambiental.

Los dictámenes emitidos por organismos especializados del Estado ostentan fuerza probatoria iuris tantum, pudiendo ser rebatidos únicamente por medio de otros informes técnicos.

Artículo 26. Trámite preferente. Los procesos ambientales se tramitarán sin mayor dilación, estando facultado el juzgador de realizar la declaratoria de trámite preferente al cursar la demanda. Para ello priorizará con relación a otros procesos el emplazamiento, la programación de actos necesarios para las medidas cautelares, el señalamiento de audiencias y la emisión de sentencia, en cualquier instancia.

\section{Artículo 27. Audiencias.}

27.1. Audiencia preliminar: Cerrada la fase introductoria, el juez convocará a audiencia preliminar, a la cual comparecerán las partes o sus abogados.

El juez oirá a las partes sobre los motivos y fundamentos de la demanda y de la contestación e intentará la conciliación, sin perjuicio de sugerir otras formas adecuadas de solución del conflicto.

Preservada la indisponibilidad del bien jurídico colectivo, las partes podrán transigir sobre el modo de cumplimiento de la obligación.

Obtenida la conciliación, será homologada por sentencia, que constituirá título ejecutivo judicial.

Si no se obtuviere la conciliación, si ésta fuere parcial, o si, por cualquier motivo, no fuere adoptado otro medio de solución del conflicto, el juez, en forma fundada:

- Decidirá si el proceso tiene condiciones de proseguir en la forma colectiva; 
- Podrá separar los pedidos en procesos colectivos distintos, tendientes a la tutela, respectivamente, de los intereses o derechos difusos, colectivos e individuales homogéneos, siempre que la separación represente economía procesal o facilite la conducción del proceso.

- Fijará los puntos controvertidos, decidirá las cuestiones procesales pendientes y determinará las pruebas a ser producidas, y convocará a la complementaria, si fuera el caso.

27.2. Audiencia complementaria. La audiencia complementaria se llevará a cabo, en la medida de lo posible, en el sitio donde aconteció la afectación y debe practicarse en el mismo acto, la inspección y cualquier otra clase de estudio de campo que requiera la participación de un perito.

En ella el tribunal sentenciador deberá promover las siguientes actividades:

- Recepción de todos los medios de prueba debidamente admitidos. Evacuará en la forma, orden y plazo legal, las pruebas admitidas oportunamente. Igualmente podrá el tribunal admitir otras pruebas ofrecidas extemporáneamente o no admitidas. El tribunal ordenará con las partes el modo de evacuar las pruebas, pretendiendo seguir el orden de declaración de la parte, testigos, peritos, expertos, permitiendo en todos los casos a la parte oferente interrogar primero, luego a la contraria solicitar adiciones y aclaraciones, y finalmente el tribunal preguntará por medio de sus jueces.

- Los abogados, dentro del tiempo otorgado se referirán a los aspectos más importantes vividos con la inmediatez de la prueba, indicando los hechos relevantes que a su criterio han sido probados o no, las razones jurídicas que fundamentan o desvirtúan la pretensión, doctrina y jurisprudencia, así como los principios de derecho aplicables al caso, por las cuales debe ser acogida o rechazada la demanda. El tribunal les otorgará a los abogados otro período prudencial para replicar argumentos de la parte contraria.

- El tribunal se retirará a deliberar y señalará hora y fecha para el dictado de la parte dispositiva de la sentencia dentro de las 24 horas siguientes.

- En el mismo acto del dictado oral de la parte dispositiva de la sentencia las partes podrán solicitarle adición y aclaración, la cual quedará notificada en ese mismo acto.

- A partir de la lectura integral de la sentencia y notificación en estrados, corre el plazo para la formulación de recurso de casación.

Artículo 28. Sentencia. En sentencia, el tribunal deberá fijar las responsabilidades del caso y ordenar la inmediata reparación integral del ambiente degradado, asimismo, las medidas y acciones necesarias para evitar que se incremente el daño ambiental ocasionado, determinando claramente los parámetros, medidas de restauración y compensación y el plazo propuesto para el cumplimiento de las obligaciones del responsable, así como los mecanismos de control y verificación de su cumplimiento, y cuando sea procedente, el monto de la sanción pecuniario disuasiva y la devolución de la plusvalía ambiental ilícita. Igualmente, deberá cuantificar y fijar la indemnización por el daño ambiental acontecido, indicando expresamente la finalidad ambiental que debe atenderse, así como el órgano o entidad pública responsable de darle el destino señalado. La valoración económica del daño ambiental deberá hacerse en forma integral, utilizando los métodos de valoración más apropiados para garantizar ese objetivo. 
28.1. Condena de adoptar acciones u omisiones preventivas. Si se impone en sentencia la orden de adoptar acciones u omisiones preventivas, el juzgador podrá disponer de todas aquellas que sean consecuencia directa de lo resuelto y de las que, como parte de ello, se estimen necesarias para el debido control de su ejecución y eficacia futura.

El tribunal debe apercibir a la parte condenada que, en caso de incumplimiento, se testimoniará piezas a la vía penal para que se le investigue por el delito de desobediencia a la autoridad. Tratándose de personas funcionarias públicas, sería por el de incumplimiento de deberes, sin perjuicio de otras figuras delictivas.

Si se trata de instituciones públicas o de personas jurídicas, la sentencia debe especificar sobre quién pesa la obligación de hacer efectivo lo resuelto en razón del cargo que ocupa, en el entendido de que esta alcanza a quien le corresponda desempeñarlo.

28.2. Condena por daño ambiental. Cuando se trate de una condena por daño ambiental, la sentencia dispondrá:

1. Ordenar la recomposición o reparación del ambiente, siempre que sea posible, a fin de procurar restablecer el estado o situación preexistente de la forma más íntegra posible, considerando la mejor información disponible. Se entenderá que no será posible cuando el daño sea irreversible. Solo excepcionalmente y fundado en criterios técnico-científicos, el tribunal podrá ordenar la adopción de medidas alternativas o equivalentes, en mayor beneficio del ambiente, cuando su costo sea considerablemente menor al de la recomposición. Además, puede imponer otras formas de reparación, cuando el daño no haya sido excesivo o el criterio técnico o científico recomiende, como solución idónea, la regeneración natural.

2. Si se impone a la persona responsable el deber de reparar, por sí misma, en forma integral el daño causado, la sentencia debe establecer los mecanismos para controlar y verificar el cumplimiento de esa obligación. El tribunal debe apercibir que, en caso contrario, se testimoniarán piezas a la vía penal para que se le investigue por el delito de desobediencia a la autoridad. Si el tribunal estima que la persona responsable no está capacitada para ello, técnica ni científicamente, podrá encomendar, a costa de esta, la ejecución específica a cargo de una tercera persona pública, privada u otras organizaciones civiles, que sí lo estén.

3. El plazo para el cumplimiento de las obligaciones materia de la presente Ley, será fijado por el tribunal tomando en consideración: la naturaleza de las obras o actos necesarios para reparar el daño ocasionado al ambiente y en su caso, cumplir con la compensación ambiental; lo propuesto por las partes, y la opinión o propuesta de organismos técnicos especializados del Estado.

4. De acogerse reclamos patrimoniales a título particular, cuando la parte demandante esté, técnica y científicamente, capacitada para llevar a cabo la ejecución específica de lo concedido y haya solicitado que se le autorice hacerlo, pero a cargo de la demandada, sin que esta haya manifestado objeción, podrá acogerse la petición. Lo anterior se dispone, salvo si se trata de procesos para la tutela de intereses y derechos supraindividuales.

28.3. Condena indemnizatoria. Cuando se solicite en la demanda la recomposición o reparación del ambiente o la indemnización dineraria, independientemente de la prioridad con que se formulen, se ordenará en sentencia la recomposición. Si no es 
posible, se impondrá la indemnización del daño ambiental colectivo, de manera subsidiaria.

La responsabilidad por la restauración ambiental, compensación ambiental e indemnización del daño ambiental, no es excluyente, pudiendo acumularse.

Cuando no sea posible establecer en la sentencia el importe de la condena, se fijarán las bases de la liquidación y el procedimiento para reconocer los derechos de los interesados.

28.4. Destino y finalidad de la indemnización por daño ambiental colectivo. Los recursos pecuniarios derivados de una condena indemnizatoria, en lo concerniente al daño ambiental colectivo, deben orientarse a la reparación de la afectación concreta. De no ser posible, se deben destinar a la protección, preservación, restauración o mejoramiento en general de bienes, recursos, servicios o ecosistemas, iguales o equivalentes a los afectados.

La indemnización por daño ambiental colectivo se otorga en beneficio de la colectividad a través del Fondo de Restauración Ambiental. Mientras el Fondo entre en operación, la indemnización será a favor del Estado y la sentencia ordenará que se deposite lo concedido en la Caja Única del Estado en una cuenta cliente creada especialmente para tal fin, cuyo titular será el ente público designado por el juzgador. Se elegirá a aquel cuyas competencias administrativas sean las más afines o idóneas para la recomposición del ambiente, según el daño analizado en el proceso. Dicho ente debe destinar la indemnización para ejecutar las obras de reparación y restauración necesarias, tomando en cuenta las indicaciones que el juez haya determinado en la sentencia. Además, ordenará al Ministerio de Hacienda tomar las previsiones financieras en el título presupuestario correspondiente.

28.5. Indemnización por daño ambiental individual: En los procesos donde se haya solicitado indemnización a título particular, debe otorgarse la indemnización a favor de la persona afectada directa por un daño ambiental que ha incidido sobre su patrimonio. La indemnización concedida a la persona afectada directa, no deberá comprender lo relativo al daño ambiental colectivo, ni tampoco lo que, de algún modo, haya sido ordenado o concedido anteriormente o en el mismo proceso, con el fin de reparar o restaurar el daño ocasionado al ambiente, y que con ello haya resultado beneficiada.

28.6. Sanción pecuniaria con fines disuasivos. En cada caso, el órgano jurisdiccional debe prever que la sanción económica sea claramente suficiente para lograr los fines de inhibición y prevención general. Su monto se fija prudencialmente en sentencia, tomando en consideración las circunstancias del caso, en especial la gravedad de la conducta del sancionado, su repercusión social, los beneficios que obtuvo o pudo obtener, los efectos disuasivos de la medida, el patrimonio del dañador, y la posible existencia de otras sanciones penales o administrativas, y tendrá como fin el destino que le asigne el juez por resolución fundada. El monto correspondiente a la sanción económica será depositado a favor del Fondo de Restauración Ambiental.

28.7. Determinación de las medidas de restauración y compensación. A la hora de determinar las medidas de reparación y compensación ambiental, el juzgador en sentencia deberá considerar:

- El criterio de equivalencia recurso-recurso o servicio-servicio; 
- Las acciones que proporcionen recursos naturales o Servicios Ambientales del mismo tipo, calidad y cantidad que los dañados;

- Las mejores tecnologías disponibles;

- Su viabilidad y permanencia en el tiempo;

- El costo que implica aplicar la medida;

- El efecto en la salud y la seguridad pública;

- La probabilidad de éxito de cada medida;

- El grado en que cada medida servirá para prevenir daños futuros y evitar riesgos como consecuencia de su aplicación;

- El grado en que cada medida beneficiará al ecosistema dañado;

- El grado en que cada medida tendrá en cuenta los correspondientes intereses sociales, económicos y culturales de la localidad;

- El periodo de tiempo requerido para la recuperación de los ciclos biológicos que fueron afectados por el daño causado al ecosistema;

- El grado en que cada una de las medidas logra reparar el lugar que ha sufrido el daño ambiental, y

- La vinculación geográfica con el lugar dañado.

De existir diversas alternativas que pudieran generar los mismos resultados positivos de reparación o compensación, el juzgador en sentencia optará por la menos onerosa para el responsable.

28.8. Control, fiscalización y vigilancia. La sentencia que impone una condena por daño ambiental colectivo debe fijar los plazos y etapas para su concreción, así como determinar los órganos de control y fiscalización encargados de controlar el cumplimiento de lo efectivamente ordenado para prevenir, proteger o restaurar los daños al ambiente.

El órgano ejecutor puede requerir periódicamente a dichos órganos, informes de los avances en la ejecución, con el fin de emitir los recordatorios necesarios cuando exista alguna tardanza u omisión, o bien para tomar otras medidas legales pertinentes en función de lo ejecutoriado.

28.9. Efectos. Las sentencias emitidas en procesos para la tutela de intereses o derechos supraindividuales o de incidencia colectiva, despliegan los siguientes efectos:

Tratándose de la tutela de intereses difusos, la sentencia gozará de eficacia de cosa juzgada material respecto de cualquier persona (erga omnes), salvo que la demanda se declare sin lugar por insuficiencia probatoria. No se perjudicarán las acciones de indemnización por daños individualmente sufridos, así reclamados, pero si la demanda es declarada con lugar, beneficiará a las víctimas y a sus sucesores; quienes podrán proceder a la liquidación en el proceso de ejecución.

En procesos de intereses estrictamente colectivos, las sentencias ostentarán efectos de cosa juzgada material respecto de quienes no hayan figurado como parte, pero limitadamente al grupo, categoría o clase, salvo improcedencia por insuficiencia probatoria. Esos efectos de cosa juzgada quedan limitados al plano colectivo y no perjudicarán intereses individuales.

Si se trata de intereses individuales homogéneos, la sentencia despliega efectos de cosa juzgada material respecto de cualquier persona afectada, cuando la sentencia es 
estimatoria. En caso contrario, las personas interesadas no litigantes, pueden demandar a título individual.

Las personas que, a pesar de no haber sido litigantes en el proceso principal, se les extiende los efectos de una sentencia estimatoria deberán hacer valer sus derechos en el proceso de ejecución.

Los efectos de cosa juzgada en procesos de tutela de derechos supraindividuales, quedan limitados a lo colectivo y no perjudican intereses individuales que se hayan pedido o puedan plantearse a futuro.

En las relaciones jurídicas continuadas, si sobreviene modificación en el estado de hecho o de derecho, la parte puede solicitar la revisión de lo decidido en sentencia.

Por último, si la demanda es denegada con base en la prueba recibida, cualquier persona legitimada puede intentar otra acción con idéntico fundamento; siempre y cuando haya surgido prueba nueva y sobreviniente, y que por dichas razones no se hubiese podido ofrecer o producir en el proceso.

28.10. Dimensionamiento y graduación de los efectos. El tribunal está facultado para graduar y dimensionar los efectos de la sentencia en el tiempo, espacio o materia, cuando la estabilidad socio ambiental y la seguridad jurídica así lo impongan. Sin embargo, tal potestad debe ser ejercida con especial cuidado y cautela, atendiendo los postulados de razonabilidad y proporcionalidad, entre otros, a efecto de lograr el justo equilibrio entre los derechos ambientales y el resto del elenco de derechos y garantías.

El juzgador podrá abordar temas y extender sus fallos a cuestiones no sometidas expresamente a su consideración por las partes, supliendo las falencias de las alegaciones de las mismas y cumpliendo con ello el deber de garantizar el interés público ambiental, sin que con ello implique violación al principio de congruencia. Tampoco se quebrantará el citado principio, en aquellos casos de pronunciamientos sobre extremos no pedidos que sean una consecuencia legal de la decisión o necesaria para la eficacia de la sentencia.

28.11. Publicación. De las sentencias que protejan intereses supraindividuales, se ordenará publicación de un extracto de la demanda, así como del resultado de la sentencia o los términos del arreglo final, en un diario de circulación nacional.

Además, se ordenará su inscripción en el Registro de Procesos Ambientales, en el cual se hará constar además de la sentencia o del acuerdo conciliatorio homologado, las condenas que recaigan sobre los demandados y el cumplimiento de las mismas.

Artículo 29. Ejecución de sentencia. El proceso de ejecución procederá cuando haya adquirido firmeza el pronunciamiento por ejecutar, o se hayan cumplido las condiciones dispuestas en este. Iniciará de oficio, salvo si se requiere gestión de parte para ejecutar total o parcialmente lo otorgado. La parte ejecutante presentará la solicitud respectiva, o en su caso, la demanda de ejecución.

El tribunal que emitió la resolución u homologó el acuerdo judicial o extrajudicial, será competente para conocer del proceso de ejecución. La resolución por ejecutar deberá ser cumplida, en la forma y los términos consignados en ella. Para su pronta y efectiva ejecución, el juzgador dispondrá las medidas necesarias, aunque no se hayan ordenado en la resolución por ejecutar, siempre que no se altere lo otorgado o concedido en ella. 
Si se ha omitido consignar las prevenciones referidas a las sanciones aplicables en caso de incumplimiento, se harán las respectivas advertencias, a fin de garantizar la efectividad de lo resuelto.

Para la ejecución de sentencias de tutela de intereses supraindividuales se seguirán las disposiciones generales establecidas. Cuando proceda la extensión de los efectos de la sentencia, siguiendo el trámite incidental, el tribunal resolverá, según los datos, características y requisitos establecidos en la sentencia, si reconoce a los solicitantes los beneficios de la condena. Por cada interesado, se formará un legajo separado. El tribunal podrá delegar en una institución reconocida la forma de pago de la indemnización, según los parámetros fijados en la sentencia. Esta deberá rendir cuentas conforme lo establezca el tribunal.

Artículo 30. Recursos. Las resoluciones judiciales serán recurribles por los medios y en los casos expresamente establecidos. Podrán impugnarlas únicamente las personas perjudicadas por estas, incluidos los terceros, en los plazos y condiciones dispuestos por ley.

Son medios de impugnación la revocatoria, la apelación, la casación y la revisión.

Contra las providencias no cabrá recurso alguno; sin embargo, los jueces podrán dejarlas sin efecto o modificarlas bien de oficio o en virtud de observaciones escritas $u$ orales de la parte interesada. Si juzgare improcedentes las observaciones no deberá dictar resolución alguna.

- Recurso de revocatoria. Será procedente la revocatoria contra los autos. Deberá presentarse en tiempo y resolverse inmediatamente cuando la resolución impugnada fuere escrita, y en el mismo acto de manera oral si fuere contra cualquier resolución dictada en audiencia. Si no se interpusiere en esa oportunidad precluiría el derecho a recurrir. Los jueces la acogerán de ser procedente. En caso de que el tema fuere complejo o merezca discusión, a criterio del juzgador, se oirá a la contraria en el mismo acto. Se decidirá de inmediato, manteniendo, modificando o dejando sin efecto la resolución, y sólo se asentará lo resuelto finalmente.

- Recurso de apelación. Cuando además del recurso de revocatoria sea procedente el de apelación, ésta siempre será subsidiaria de aquella y se interpondrá en el mismo acto o escrito. Si se denegare la revocatoria, obligatoriamente los jueces se pronunciarán sobre la admisión de la apelación.

Cabrá recurso de apelación únicamente contra las resoluciones expresamente señaladas, entre ellas, la que declare inadmisible la demanda; la que deniegue, revoque o cancele medidas cautelares; el auto que resuelve sobre excepciones previas, cuando el pronunciamiento no produzca cosa juzgada material; contra sentencias incidentales o interlocutorias, salvo que la ley les niegue la alzada; resuelvan sobre acumulación o desacumulación de procesos; decidan la interrupción o suspensión del proceso.

La apelación adhesiva procederá cuando el apelado vencido en parte de sus pretensiones, formule recurso dentro del emplazamiento para que el superior examine los extremos de la resolución que le fueron desfavorables. No será admisible la adhesión si se rechaza el apelado o se declaró desierto. El derecho establecido en esta disposición será extensivo a los terceros intervinientes.

El recurso de apelación por inadmisión deberá presentarse ante el superior y procederá cuando se deniegue ilegalmente una apelación, en los términos de ley. 
Interpuesto el recurso, el superior dando sus razones lo rechazará de plano si fuere impertinente. En caso contrario resolverá sin trámite alguno, si fuere posible. Podrá pedir información por fax, teléfono o cualquier otro medio, sin que sea necesario pedir el expediente físico.

- Recurso de casación. El recurso de casación procederá para la recta interpretación de la ley y la doctrina jurisprudencial, y se regirá por las reglas del Código Procesal Contencioso Administrativo.

Bajo pena de inadmisibilidad, el recurso deberá tener causa y estar suficientemente motivado. Combatirá con claridad y precisión los fundamentos de la sentencia impugnada y procederá cuando sus vicios sean determinantes y justifiquen la modificación del fallo.

Dentro de cada tipo, de forma o fondo, los motivos deberán consignarse clara y precisamente separados, enumerados y titulados. En cada caso, deberán indicarse las fuentes normativas violadas y la forma como operó la infracción, sin embargo, la cita equivocada de una norma o un principio no exime de su pronunciamiento.

Solo procederá por razones procesales cuando se violen las normas de procedimiento tenidas como causales expresamente, y por razones de fondo cuando en la sentencia se infrinja cualquier tipo de fuente de derecho.

Al dictar la sentencia el Tribunal de Casación procederá de la siguiente forma:

Si la sentencia se casare por vicios de carácter procesal, el Tribunal de Casación anulará el fallo con reenvío al Tribunal de origen, quien repondrá los vicios y lo fallará de nuevo con arreglo a derecho, con repetición, incluso, de las audiencias de pruebas. El reenvió se interpretará de manera restrictiva.

Cuando se pueda reponer el vicio, sin infringir el principio de la inmediación, tratándose de la incongruencia, falta de motivación o fundamentación, el Tribunal de Casación redimensionará el fallo dictando otra sentencia sin necesidad de reenvío.

Si el Tribunal de Casación anulare y casare la sentencia en cuanto al fondo, dictará otra en su lugar sobre el material de hecho del fallo recurrido y reemplazará los fundamentos jurídicos erróneos cuando los estime incorrectos. Para ello tomará en cuenta las defensas de la parte contraria a la recurrente, omitidas o preteridas en la sentencia impugnada, si por haber resultado victoriosa esa parte, no hubiere podido interponer el recurso de casación.

Si la casación se hubiere interpuesto por vicios procesales y vicios de fondo, el Tribunal solo se pronunciará respecto de los de procedimiento si fuere procedente, omitiendo cualquier pronunciamiento de fondo, y sobre el fondo solo se pronunciará si no se han cometido infracciones susceptibles de invalidar el procedimiento.

Si se declarara sin lugar se condenará en costas a quien lo hubiere interpuesto.

- Recurso de revisión. El recurso extraordinario de revisión procederá contra la sentencia firme con eficacia y autoridad de cosa juzgada material, conforme a las causales y el procedimiento establecidos en la normativa procesal civil. El plazo y el dictado o emisión de la sentencia se regirán por lo dispuesto para el recurso de casación.

- Efectos de los recursos. La admisión de recursos contra resoluciones que ponen fin al proceso produce efecto meramente devolutivo, salvo cuando la fundamentación 
fuere relevante y pudiere resultar para la parte una lesión grave y de difícil reparación, caso en el cual el juez podrá atribuir al recurso, efecto suspensivo.

El tribunal de primera instancia conserva la competencia en los supuestos de apelación contra resoluciones emitidas en asuntos tramitados en legajo separado, en medidas cautelares y tutelares y para la ejecución provisional.

Artículo 31. Costas. La sentencia estimatoria condenará al demandado al pago de costas. Si la sentencia fuere desestimatoria, sólo se condenará a la parte actora al pago de costas cuando haya litigado de mala fe. En este supuesto, la persona física o la asociación actora y los directores responsables por la presentación de la demanda, serán solidariamente obligados, sin perjuicio de la responsabilidad por daños y perjuicios.

Artículo 32. Gratificación financiera. Cuando el legitimado para interponer un proceso de tutela de intereses supraindividuales fuere una persona jurídica sin fines de lucro, el tribunal podrá fijar una gratificación financiera, cuando su actuación hubiere sido relevante en la conducción y éxito de la acción colectiva.

Artículo 33. Fondo de Restauración Ambiental. Créase el Fondo de Restauración Ambiental que tendrá como objeto el pago de la reparación de los daños que sean ocasionados al ambiente, así como pago de los estudios e investigaciones que el juez requiera durante el proceso ambiental.

La información relativa a la operación del Fondo será pública. Se constituirá por medio de la figura del fideicomiso, estará bajo la vigilancia, supervisión y coordinación del Ministerio del Ambiente, y su patrimonio se integrará con:

I. Indemnizaciones por daño ambiental colectivo.

II. Sanciones pecuniarias disuasivas y plusvalía ecológica ilícita.

II. Los demás recursos que obtenga por cualquier otro concepto.

El Ministerio del Ambiente y Energía expedirá las bases y reglas de operación del fondo, en la que tendrán participación la Procuraduría, las instituciones académicas y las organizaciones sociales.

El patrimonio del Fondo se destinará a la reparación de los daños al ambiente, al pago de los estudios e investigaciones que el juez requiera durante la tramitación del proceso ambiental, y tratándose de sanciones pecuniarias disuasivas, al fin destino asignado por el juez en sentencia.

El Fondo se sujetará a los procedimientos de control, auditoría, transparencia, evaluación y rendición de cuentas que establecen las disposiciones legales aplicables.

Artículo 34. Prescripción. Es prescriptible la acción por daños a través del ambiente o daños ambientales individuales. El plazo de inicio de la prescripción comienza a correr desde el momento en que el sujeto dañado, la víctima, el damnificado directo o particular damnificado, el afectado individual o colectivo, tuvieren conocimiento fehaciente, cierto, pleno y acabado del daño ambiental en un sentido amplio o de los perjuicios que sufre en su persona o bienes por alteración del ambiente. Tratándose de daño continuado, su plazo comienza a correr a partir del último acto de violación repetitiva, continua e ininterrumpida, o sea, cuando cesa y se produce su verificación total y definitiva, siendo que mientras la acción u omisión dañosa se siga generando, la prescripción no corre. 
La citación válida en los procesos colectivos interrumpe el plazo de prescripción de las pretensiones individuales y transindividuales directa o indirectamente relacionadas con la controversia, y retrotrae sus efectos a la fecha de la presentación de la demanda.

Son imprescriptibles las acciones precautorias, preventivas, de recomposición, compensación e indemnización del daño ambiental colectivo.

Artículo 35. Registro de procesos ambientales. Créase el Registro de procesos ambientales de acceso público donde se inscribirán los asuntos tramitados, el estado del proceso, los fallos emitidos y su cumplimiento, condenas que recaigan sobre los demandados y cumplimiento de las mismas.

\section{Conclusión}

El derecho ambiental será efectivo cuando logre garantizar, por medio de normas procesales, el orden público ambiental y con ello, el mantenimiento y aseguramiento del equilibrio ecológico, la eficiencia económica y la equidad social entre las actuales $\mathrm{y}$ futuras generaciones. Ciertamente, queda mucho camino por recorrer.

\section{Bibliografía}

Cafferatta, Néstor, Propuesta de Ley Modelo de Daño Ambiental, serie Ambiente y Justicia 6, Comisión Centroamericana de Ambiente y Desarrollo, San Salvador, 2009.

Cafferatta, Néstor, Daño Ambiental Jurisprudencia, en Revista Jurídica La Ley. Año LXIII, número 131, Buenos Aires, 2003.

Cafferatta, Néstor, Prueba y nexo de causalidad en el Daño Ambiental, en obra colectiva, Volumen 3, "Meio Ambiente e Acceso à Justiça", Homenagem a Vladimir PASSOS DE FREITAS, $11^{\circ}$ Congreso Internacional de Direito Ambiental, 27 de Maio a $1^{\circ}$ de Junho de 2007, Sao Paulo, Brasil, Instituto O Direito po um Planeta Verde, Imprenta Oficial do estado de Sao Paulo, 2007.

Cafferatta, Néstor, Daño Ambiental Jurisprudencia, en Revista Jurídica La Ley. Año LXIII, número 131, Buenos Aires, 2003.

Cafferatta, Néstor., La prueba en el daño ambiental, publicado en la Revista Brasileira de Direito Ambiental, enero/marzo 2005, Editora Fiuza, vol 01, año 01, 2005.

Cafferatta, Néstor, El principio de prevención en el Derecho Ambiental, en Revista de Derecho Ambiental, número 0, noviembre 2004, Editorial Lexis Nexos, Buenos Aires, 2004. 
Cafferatta, Néstor, Prueba y Nexo de causalidad en el daño ambiental, en Revista de Derecho Ambiental, número 0, noviembre 2004, Editorial Lexis Nexos, Buenos Aires, 2004.

Cafferatta Néstor, Proceso Colectivo Ambienta a la luz de la Ley 25675 General del Ambiente, en Revista de Direito Ambiental, año 8, enero - marzo 2003, Editora Dos Tribunais, Sao Paulo, 2003.

González Ballar, Rafael, Verdades Incómodas sobre la Justicia y la Gobernabilidad Ambiental en Costa Rica, Editorial Jurídica Continental, San José, 2007.

González Ballar, Rafael. Recomendaciones para la caracterización del daño ambiental, en Temas de Derecho Ambiental, Editorial Investigaciones Jurídicas, San José, 2001.

González Ballar, Rafael. La interpretación en el Derecho Ambiental, en el libro colectivo: Derecho Ambiental y Desarrollo Sostenible, San José, Oficina de publicaciones de la Universidad de Costa Rica, 1996.

Jordano Fraga, Jesús, La responsabilidad por daños ambientales en el derecho de la Unión Europea: análisis de la directiva 2004/35, de 21 de abril, sobre responsabilidad medioambiental, en Revista Electrónica de Derecho Ambiental "Medio Ambiente \& Derecho" Universidad de Sevilla, número 12-13, setiembre 2005.

Lorenzetti, Ricardo Luis. 6 Congresso Internacional de Direito Ambiental - 10 anos da Eco-92: o direito e o desenvolvimento sustentável - Teoria geral do dano ambiental moral, en Revista de Direito Ambiental número 28 edición octubre diciembre 2002, Sao Paulo, 2002.

Lorenzetti, Ricardo Luis. Responsabilidad colectiva, grupos y bienes colectivos, Buenos Aires, 1996.

Lorenzetti, Ricardo Luis. Daño ambiental colectivo: su reconocimiento jurisprudencial, Buenos Aires, 1997

Peña Chacón, Mario, La Jurisdicción Ambiental en el nuevo Código Procesal General, Revista Medio Ambiente \& Derecho, Universidad de Sevilla, número 8, diciembre 2002, España, 2012.

Peña Chacón, Mario, Aspectos procesales de la responsabilidad por daño ambiental aplicables en la nueva jurisdicción contencioso administrativa, en Revista Judicial número 102, diciembre 2012, San José, 2012.

Peña Chacón, Mario, El derecho procesal ambiental en la jurisprudencia costarricense, Revista Iberoamericana de Derecho Ambiental y Recursos Naturales número 14, noviembre 2014, Buenos Aires, 2014. 
Peña Chacón, Mario, Régimen especial de responsabilidad ambiental de sitios contaminados, Lex, Difusión y Análisis, año XIX, número 229, julio 2014, México, 2014.

Peña Chacón, Mario y Ojeda Mestre, Ramón. Análisis crítico del proyecto de ley de responsabilidad civil por el daño y el deterioro ambiental, Revista Lex difusión y análisis, año VIII, enero 2004, número ciento tres, México, 2004.

Ojeda Mestre Ramón. La legitimación activa para el juicio de amparo en materia ambiental. Revista Mexicana de Legislación Ambiental. Enero-agosto de 2001. Año 2 No. 5 y 6.

Ojeda Mestre, Ramón, Responsabilidad por daño ambiental, Revista Lex, difusión y análisis, año VIII, diciembre 2004, número ciento dos, México.

Valls, Mario Francisco, Derecho Ambiental, Editorial Abeledo Perrot, Buenos Aires, 2008.

Zeledón Zeledón, Ricardo, ¡Salvemos la justicia¡: humanización y oralidad para el siglo XXI, Ediciones Guayacán, San José, 1998.

Zeledón Zeledón, Ricardo, Responsabilidad Ambiental, Sistemática del Derecho Agrario, San José, 2002. 